\title{
THE FINANCIAL BURDEN OF NATIONAL ROAD INFRASTRUCTURE AND THE EQUITY THEREOF: A SOUTH AFRICAN PERSPECTIVE
}

\author{
ANTON BRITS \\ britsa@unisa.ac.za \\ Department of Transport Economics, Logistics and Tourism \\ University of South Africa \\ South Africa
}

\begin{abstract}
Economic activities in South Africa during the past decade have caused, inter alia, road traffic congestion to accelerate annually and road infrastructure to deteriorate rapidly. Motor vehicle sales, correlated with economic trends and the economic empowerment of citizens, have and still are increasing at a faster rate than the supply of necessary infrastructure. As such, congestion, especially in the Gauteng area, has reached unacceptable levels during peak hours, necessitating the upgrading and continual maintenance of these roads and other national roads. The financial burden of upgrading and maintaining road infrastructure is enormous and, although the South African government makes contributions, an income from the road infrastructure is necessary to sustain quality infrastructure. However, a road-user paying approach, especially the structure thereof, should be acceptable to society in terms of economic efficiency and various means of equity. This article reviews the relevance of a road-user paying approach as applied in South Africa.
\end{abstract}

\section{INTRODUCTION}

The well-known characteristic of transport, namely that it is very seldom demanded in its own right but for some benefit at a destination, makes transport different from the demand for other goods, since a produced service cannot be stored for a later date. Transport, with its infrastructure as an indispensible production element, is an important input for the efficient functioning and development of the socio-economic activities of a nation. 'Transport is central to development. Without physical access to jobs, health, education and other amenities, the quality of life suffers; without physical access to resources and markets, growth stagnates and poverty reduction cannot be sustained' (World Bank, 1999: 1). Travellers will benefit at their destination while freight transporters will take cognisance of the transport cost in their production function. In the short term, a change of generalised transport costs will influence the demand for products and services; in the medium term, spatial interactions will be affected, and in the long term substantial economic growth in terms of relocation and expansion may be a result of competitive forces generated by transportation. 
Pricing and regulation in transport coincide with the fundamental aspects of a society and cannot be left completely to the free market system. The involvement of public authorities may distort the free market interaction between the supply of transport that represents production cost and demand for transport that represents the economic utility of such a service. The pricing of transport may therefore not be market related. Historically, transport infrastructure is also perceived as public good and therefore regarded as a fundamental right to be mobile (PATS, 2000: 13-14).

In the South African context, the South African National Roads Agency Ltd (SANRAL), formed in 1998, has been entrusted by the South African government 'to provide and manage a world-class, sustainable national road network as cost-effective as possible, in order to stimulate economic growth and improve the quality of life of all South African people' (SANRAL, 2005: 6). SANRAL is responsible for 1573 dual roads, 550 km four-lane roads, $14047 \mathrm{~km}$ two-lane roads, $1288 \mathrm{~km}$ build-operate-transfer toll roads, $1832 \mathrm{~km}$ state toll roads and $13050 \mathrm{~km}$ non-toll roads (SANRAL, 2009c). Various provincial roads are in the process of being reallocated as national roads and will therefore become SANRAL's responsibility and further pressurise its budget.

Funding for SANRAL's national non-toll roads is allocated by the National Treasury which levies a general fuel tax in terms of the Customs and Excise Act 91 of 1964 (Republic of South Africa, 1964). The fuel levy varies monthly according to international fuel prices. The income from the fuel levy tax is, however, combined with other state revenues and allocated according to priorities, as is also the case in Latin America (Roth, 1996: 59). However, since other priorities such as poverty, education and health may be ranked higher than expanding road infrastructure, only approximately 33\% of the South African fuel levy is allocated to roads (Copley \& Shaw, 2007: 8). As such, a cumulative SANRAL's budget deficit of 10.8 billion rand has developed between the financial years 2001/02 and 2007/08 (SANRAL, 2005: 25).

In the absence of an adequate allocation from the fuel levy, it is evident that, for SANRAL to succeed in its mission 'to provide and manage a world-class, sustainable national road network as cost-effective as possible', a funding approach such as a road-user pricing system is a necessity. SANRAL has therefore sought alternative sources of finance for road infrastructure and opportunities to reduce its dependence on tax-based revenues (SANRAL, 2009a: 12).

The socio-economic acceptance in the South African context of a road-pricing approach, in terms of economic efficiency and various means of equity, is important for economic and social adhesion and support. In the sections below, the South African situation, National Treasury allocations, road-user principles, economic efficiency and equity requirements, and the Gauteng Freeway Improvement Project (GFIP) are discussed. 


\section{RESEARCH STRATEGY}

The objective of the research on which this article is based was to evaluate the financial burden of national road infrastructure as implicated by pricing approaches, with specific reference to economic efficiency and equity adherence.

Detailed data of individual road users were not retrieved because of the comprehensiveness of the data and the cost of collecting such data. Secondary data was however utilised, evaluating qualitatively the financial burden of the national road infrastructure and the equity thereof. A literature review was undertaken to evaluate the socio-economic acceptance of a road-user pricing system, based on economic efficiency and various forms of equity as concluded by the Pricing Acceptability in the Transport Sector (PATS) (PATS, 2000) research. Thereafter the compliance of the GFIP project to the latter was evaluated.

\section{DISCUSSION}

\section{The South African situation}

Funding sources for the national road network in South Africa (SA), other than from the state budget, are the responsibility of SANRAL. Toll revenue, capital market loans, bonds and private sector investment are utilised as funding sources. Toll revenue is subject to the provisions of The South African National Roads Agency Limited and National Roads Act 7 of 1998 (Republic of South Africa, 1998) and is raised by means of the road-user pricing approach, not only for the initial construction of the roads but also for the maintenance and upgrading thereof, whereas loans are raised from the capital and money markets. Mediumand long-term bonds are issued, guaranteed by the South African government. Private sector investments as a means of funding are obtained through public-private partnerships (PPP) and concession toll roads (SANRAL, 2005: 17).

Private/concessionaire objectives of road financing, by means of a road-user pricing approach are different from those of public financing objectives. The income from toll revenue by means of PPP agreements (currently only applicable to three SA national roads), where the private partner is actually the concessionaire, is based on the sustainability of the infrastructure. The road user is thus tolled according to the 'use of the road' rather than for the purpose of preventing congestion, since the latter is very seldom applicable. Cognisance should however be taken of the point that 'when comparing the net present benefits of projects without tolling and with tolling ... it is in the financial interest of private toll scheme developers to undertake road-works to the extent of what tolls road users would be willing to bear, while lesser road-works without toll-financing may be adequate' (Haiden \& Floor, 2003: 6). 
The PPP concept is based on the build-operate-transfer (BOT) approach and the responsibility for income by means of the road-user pricing principle will be as agreed by both public and private participants. The concession toll road refers to a situation where the concessionaire is responsible for the funding, design, building, operating, maintenance and tolling of the road. The concession period is usually 30 years, after which the asset is reverted back to SANRAL in a specified condition (SANRAL, 2005: 17). The rationale for road-user pricing should be linked to economic efficiency, financial balance, equity and environmental sustainability. This will be an indication of the diversity of stakeholders, namely, road users, government and the public in general (Hensher \& Brewer, 2001: 172). The PPP concept furthermore implies that prospective concessionaires have to conduct comprehensive traffic modelling because the financial viability and sustainability of a BOT project will depend on adequate toll revenues generated from road users. Scrutinising of traffic estimates is therefore important. 'Without such scrutiny, the concessionaires face serious financial risks' (Oberholzer, Van Zyl, Andersen, Skrbinsek \& Burnett, 2001: 2).

Toll revenue from already established facilities should be used to repay capital market loans for the initial investment in these facilities and to improve and maintain the road infrastructure. Such a road-user pricing approach may however be in conflict with economic efficiency in terms of price-relevant marginal costs for transport infrastructure, and may aggravate the conflict between efficiency and equity of transport infrastructure pricing policies (Jansson, 2001: 358). On the demand side, reliable user information is of utmost importance. As an example, the lack of information regarding the TRAC N4 (Maputo corridor) toll concession has resulted in the tolling process impacting negatively on local perceptions of PPPs. 'There has been a lack of openness vis-à-vis the concession agreement. Many local residents are outraged that placing tolls on the N4 will separate them from their schools, jobs and the main shopping centres in Nelspruit' (Taylor, 2000: 8).

The public approach in South Africa is that SANRAL toll revenue be earmarked for the financing of upgrading and maintaining the roads which will indirectly alleviate congestion, such as experienced on the Pretoria-Johannesburg N1 freeway. The road-user pricing objectives therefore relate to the generation of investment and maintenance funds, where such funds are not available from the government budget. However, the road infrastructure market based on a pricing approach as proposed and implemented by SANRAL in general, reveals attributes of a public monopolistic market environment (Samuelson \& Nordhaus, 1986: 509) and therefore may necessitate an independent regulator protecting road users' interests.

\section{Inadequate National Treasury allocations versus toll revenue}

In SA, only 5.3 million of the total population (fractionally less than 45 million) pay income tax (National Treasury, 2008: 31). With various newly planned social strategies, such as a 
social health care system, a social grant system for the poor to be financed mainly from income tax funds, and a new tax on vehicles designed to curb carbon dioxide emissions also planned, it is evident that the income tax payer will carry a huge tax burden plus additional planned road-user payments, such as in the Gauteng and other regions.

A review of SANRAL's Declaration of Intent for 2005-2008 and 2009-2012 revealed that inadequate financial allocations for national road infrastructure from the National Treasury is not questioned but is rather used as motivation for a road-user pricing approach. The latter is evident notwithstanding that the road user is already burdened by means of a fuel levy tax, a provincial licences tax, and an acknowledgement by the previous Minister of Finance, Trevor Manuel, that inadequate allocations '... is an emphasis that cannot continue for too long, because the curve that describes the decay of inadequately maintained economic assets become dangerously steep if relative neglect persists beyond a few years' (SANRAL, 2009a: 28).

Cognisance should be given to and lessons learned from developments in the United Kingdom where the government tends to regard quality freeway infrastructure as unaffordable, and therefore the tolling of such facilities focused on the financing thereof rather than efficient charging for the use of the infrastructure. The government also appears to link PPPs 'to government funding priorities and not to cost, per se. The involvement of the private sector is a means to deliver more road infrastructure in a context where government sees its relevance, but is not prepared to spend on this, relative to commitments to other areas such as health, education police, etc.' (Hensher \& Puchett, 2005: 380).

The revenue from the South African fuel levy increased $54.8 \%$ cumulatively between 2002/03 and 2007/08 financial years, or $9.1 \%$ annually. During the 2007/08 financial year alone, the income from the fuel levy was R23.74 billion and the provincial income from motor vehicle licences, R3.6398 billion (National Treasury, 2008: 6, 15 \& 16). It is therefore questionable why an adequate allocation from the National Treasury is not made, and why SANRAL does not question the financial allocations made, because for the 2007/08 financial year the allocation to SANRAL in relation to the fuel levy was only $10.43 \%$ (see Table I). SANRAL's cumulative budget deficit of R10.8 billion rand between the 2002/03 and 2007/08 financial years represents $45.49 \%$ of the fuel levy tax income for only the 2007/08 financial year. The allocation of only $10.43 \%$ of the fuel levy for National Roads/SANRAL during, inter alia, the 2007/08 financial year indicates that the user-pay principle for national roads as proposed by SANRAL will constitute a substantial double road-user payment. SANRAL and the National Treasury should consult to alleviate such double road-user payment. 
Table I: National Treasury allocation to SANRAL versus fuel levy tax and vehicle licences

\begin{tabular}{|c|c|c|c|c|c|c|}
\hline $\begin{array}{c}\text { Description } \\
\text { (R'000) }\end{array}$ & $\begin{array}{c}\text { SANRAL's } \\
\text { budget } \\
\text { request }\end{array}$ & $\begin{array}{c}\text { National } \\
\text { Treasury } \\
\text { allocation to } \\
\text { SANRAL }\end{array}$ & Fuel levy tax & $\begin{array}{c}\text { Motor } \\
\text { vehicle } \\
\text { licences } \\
\text { Provincial } \\
\text { tax }\end{array}$ & $\begin{array}{c}\text { Total: } \\
\text { fuel levy } \\
\text { +vehicle } \\
\text { licences }\end{array}$ & $\begin{array}{c}\text { \% SANRAL } \\
\text { allocation } \\
\text { from fuel } \\
\text { levy }\end{array}$ \\
\hline $2002 / 03$ & 1394686 & 1061060 & 15333800 & 2121400 & 17455200 & 6.92 \\
\hline $2003 / 04$ & 1854556 & 1170556 & 16652400 & 2538000 & 19190400 & 7.03 \\
\hline $2004 / 05$ & 2551536 & 1440780 & 19190400 & 2694900 & 21885300 & 7.51 \\
\hline $2005 / 06$ & 3715796 & 1756479 & 20506700 & 3299700 & 23806400 & 8.57 \\
\hline $2006 / 07$ & 5222250 & $1901060^{\star}$ & 21844600 & 3605800 & 25450400 & 8.70 \\
\hline $2007 / 08$ & 5451457 & $2476112^{\star}$ & 23740500 & 3639800 & 27380300 & 10.43 \\
\hline
\end{tabular}

Adapted from National Treasury, 2008:15-16; SANRAL, 2005:25. *Anticipated allocation from National Treasury

\section{SA road-user pricing approach}

The increasing utilisation of road-user pricing as a means of substituting government funding during the past decade is questionable in terms of the actual objectives of such a policy in terms of established marginal cost pricing theory (Bonsor, 1984: 37). A road-price mechanism should aim at the effective allocation of scare economic resources in establishing sustainable road capacity. This may influence road-user behaviour and environmental impacts. Revenue generated through the road-user pricing approach should be used for financing and maintaining the exact road infrastructure from which the revenue was generated. The question, however, is the allocation priorities of revenue. Ongoing debates globally through 'considerable efforts of research and policy in the past years' (Walter \& Suter, 2003: 1) indicate that different weights are given to different price functions. Predominantly the European approach reflects a neo-classic micro- and welfare economics approach and therefore emphasises efficiency with a pricing approach which is based on short-run social marginal costs. In contrast with the latter, cost recovery requirements should be the objective of the pricing approach and therefore the emphasis should be on sustainable pricing and investment schemes (Walter \& Suter, 2003: 2). The historical under-funding of the road system in SA, however, necessitates financial sustainability which is linked with network classification and condition, institutional arrangements, funding mechanisms and capacity for delivery, to ensure system sustainability (National Department of Transport, 2006: Section 5).

The SA road-user pricing approach by the public and private/concessionaires entities is different in terms of the ultimate financial objective of the toll road project. SANRAL's financial objective, as a public entity, will be that of a financial break-even situation, whereas the financial objective of private concessioners will be a viable return on capital and minimisation of the risks associated with the outcome of the project. In general, the following procedure is followed by SANRAL to implement a road-user toll. A feasibility study 
is firstly done in terms of the total project/toll road costs, maintenance and operating costs, traffic volumes, road-user savings, toll implementation strategy, and a financial analysis. The total project costs are calculated in terms of the necessary structures, the road works and other aspects such as toll facilities and land acquisition, to establish the total project costs. A socio-economic impact assessment is then undertaken to assess the project's economic and financial feasibility. Traffic volumes are determined by, inter alia, the aggregated network transport model SATURN (Simulation and Assignment of Traffic to Urban Road Networks). A modelled traffic diversion curve is determined to establish a toll rate based on a percentage of road-user savings which will generate an acceptable rate of traffic, and for which users are prepared to pay. Road-user costs are based on vehicle operating costs, time value of road users and accident costs. Average vehicle operating costs and travel times are derived from predicted speeds of different vehicles on the designed road conditions, the expected traffic volumes and vehicle composition. A distinction is made between the time value of commuter travel, business travel and social/other travel based on stated preferences and revealed preferences. Accident rates are derived from historical data. A total road-user saving is then determined based on the above and a time-related growth pattern correlated with increasing traffic volumes over time. A toll tariff is then based on an acceptable percentage (usually $80 \%$ ) of the total savings of user costs. The financial analysis is usually based on a 30 -year project period and an $8 \%$ discount rate, which are the recommended values by the Development Bank of Southern Africa (Infrastructure Consortium for Africa, 2007; Van Niekerk, 2009b).

However, according to SANRAL's newly published Declaration of Intent (SANRAL, 2009a: 30) other 'toll-tariff structures' have to be investigated because of the 'volatility of construction, maintenance and operation costs' of roads. A cost-plus approach is considered because the user-benefit model, which is based on a tariff of approximately $80 \%$ of road-user benefits, exceeds the value of the tariff. 'The cost-plus model is based on the actual cost of providing the toll road, a margin of which is used to determine the tariff. The appropriate structure will be adopted to maximize the benefits to the road users' (SANRAL, 2009a: 30).

Extensive research of transport pricing strategies was done in Europe (PATS, 2000). The research project, namely, Pricing Acceptability in the Transport Sector (PATS) comprises four parts or deliverables. One of the deliverables is 'to explore the concept of acceptability in the light of the complex interplay between efficiency, fairness and feasibility of implementation'. This interplay relates to economic, social and political, technological and functional, and legal and regulatory issues which will directly influence acceptability. The first of these issues relates to economic efficiency, which should be the main objective for a road-user pricing approach. The second issue, social and political, relates to fairness which may be in conflict with the economic efficiency, whereas the third issue, technological and functional, takes into consideration the technological solutions required for transport pricing also influencing 
economic efficiency. The fourth issue, legal and regulatory, is concerned with efficient pricing schemes. Equity in various forms is the norm for justifying acceptance (PATS, 2000: 3). Kocak, Jones and Whibley (2005: 392) also emphasise the significant role of equity for social support of a road-user pricing system. With the initial notification of the system, concerns are largely based on, inter alia, equity, effectiveness and preservation of privacy, and therefore acceptance in general tends to be not more than $30 \%$.

\section{Economic efficiency}

'Pricing plays a major role in transport policies in many countries. The well-known motivations of pricing policies are the promotion of efficiency and equity. Efficiency leads to the rule that prices are based on marginal social costs implying that the marginal benefits of transport activities equal the marginal social costs' (Rietveld, 2006: 1). However, it is also detected by the Acceptability of Fiscal and Financial Measures and Organisational Requirements for Demand Management (AFFORD) research project that charges and taxes for transport may have little connection to costs and are rather related to broader fiscal policies. 'The gap between the marginal costs and actual charges is particularly evident in urban road transport where current pricing mechanisms typically make little or no attempt to reflect concentrations of transport activity in time and space and hence of transport induced costs' (AFFORD, 2001: 2).

The fundamentals of economic efficiency are concerned with the allocation of scarce resources. In terms of producing road infrastructure and the pricing for the use thereof, economic efficiency is achieved by maximising the sum of consumer and producer surplus, which is also defined as the social surplus (Ubbels, 2005: 4). The theoretical feasibility of road-user pricing is based on an elementary economic analysis. In this analysis, all road users are regarded as identical except for their different marginal costs when using the road. However, when the road becomes congested, the individual/private road user's marginal costs (MPC - or marginal private costs) are less than the accumulated marginal costs of all road users, which is termed the marginal social costs (MSC). The point of intersection of these cost curves with the demand curve (sloping downwards from left to right as traffic increases) portrays that in a free market situation, the number of private trips will be more than a social optimum of road users, since private trips are not burdened with the external costs they create for other road users. A road-user tariff equal to the difference between MSC and MPC (at the point of intersection of MPC with the demand curve) will therefore equate to a social optimum. The revenue from this tariff will yield a social benefit. However, all road users, except the authority levying the tariff, are worse off. Road users continuing to use the road may experience a net welfare loss since the value of time gain may be less than the tariff for using the road (Verhoef, 1996: 186-87). 
The efficiency of road-user prices, based on MSCs, requires that the marginal benefits of the transport involved be equal to the MSCs. MSCs depend on 'the costs related to time devoted to transport, costs of inputs acquired via the private market (for example with car use), costs related to the services rendered by the public sector (for example most of infrastructure) and external costs imposed on others (pollution, congestion)' (Rietveld, 2006: 1). Therefore, the conditions for optimum allocation of resources are, first, that road users should pay a toll for externalities as a result of the road use, and secondly, that optimum investment should be 'where the discounted sum of marginal congestion cost savings is equal to the marginal cost of extending the infrastructure' (Raux \& Souche, 2004: 194). The theoretical feasibility of road-user pricing was quantified by Pienaar and Nel (2009: 45-51) to indicate its practical relevance. The demand and cost functions were based on empirical data of the morning peak on the N1-Table Bay Boulevard entrance to Cape Town. They concluded, 'Road congestion paying can be instrumental in ensuring that those trips whose cost is more than their value can take place in an alternative way so that, or at a time when, their value exceeds the cost they impose.'

The above user-pay approach attempted to achieve economic efficiency. However, the user-pay principle may be in conflict with economic efficiency since a tariff that covers all costs does not coincide with the marginal cost principle (Jansson, 2001: 358). The latter may make a significant contribution when the congestion component or environment externalities are significantly high (Raux \& Souche, 2004: 196). However, models such as the Roads Economic Decision model (Archondo-Callao, 2004: 1) uses a consumer surplus approach, measuring benefits as reduced transport cost, as opposed to a producer surplus approach which measures the value added or generated benefits to productive users in the project zone of influence.

SANRAL's approach to the 'user pay' principle, namely, 'the revenue is used to improve the road infrastructure, to service debt on the toll network and to ensure a well maintained road network for the road user' (SANRAL, 2005: 17; Infrastructure Consortium for Africa, 2007) does not relate to, or attempt to consider economic efficiency, since optimisation of the sum of consumer surplus and producer surplus is not considered. Toll tariffs are levied at the expense of the consumer surplus. The actual detail of the process of calculating a toll rate per kilometre is unfortunately not available, notwithstanding that from the point of view of the road users and society it is important that 'all relevant costs and benefits are stated explicitly and in a transparent way. Additionally, it is desirable that the pros and cons are weighted without distortion in the political decision-making process' (PATS, 2000: 5).

\section{Equity of road-user pricing}

The issues of equity relate to the reactions of road users and other affected groups towards a road-user pricing approach. Raux and Souche (2004: 193) stated that 'equity involves 
not only equality between modes and users and between operators, but also the risk of increasing inequalities between users and consumers, and the desire to preserve social or spatial solidarity'.

Although considerable transport research has been done in the European Framework, such as the AFFORD project (Walter \& Suter, 2003: 1) and the Socio-Economic Principles for Price Acceptability project (PATS, 2000), evidence of research of this nature in SA is limited (Oberholzer et al., 2001; Haiden \& Floor, 2003; SANRAL, 2005: Copley \& Shaw, 2007; Infrastructure Consortium for Africa, 2007; Pienaar \& Nel, 2009; Van Niekerk, 2009a; SANRAL, 2009a). The only SANRAL reference in terms of public acceptance is '... the delivery of the toll-road programme remains subject to public acceptance of such projects, which is determined through the Intention to Declare a Toll Road process, SANRAL's ability to raise finance on the capital markets and political support for the "user-pays" principle' (SANRAL, 2009a, Section 1: 12). The Intention to Declare a Toll Road process is however not available, implying a non-transparent user-pays principle.

The PATS project based their investigation on the assumption that 'the socio-economic principles of transport pricing acceptability is that acceptability relies at least on the two conditions of efficiency and fairness' and 'the corollary of this assumption is that in order to be acceptable a transport policy must at least reach a minimal degree of efficiency and a minimal degree of fairness' (PATS, 2000: 14). Perceived insufficient economic efficiency and unfair policy measures are therefore rejected. The South African National Department of Transport (NDoT) (2006: Section 5.7.2) acknowledged the necessity of fairness by stating that 'policy regarding toll roads should be reviewed, particularly with a view to compensating low-income group users and in respect of certain equity issues.'

The principles for justice as equity were identified by Rawls (1971: 302) as the principle for liberty, the principle of equal opportunity, and the principle of differences. Based on these equity principles, the types that relate to transport pricing, and which have been studied intensively by the PATS project, are territorial equity, horizontal equity and vertical equity (PATS, 2000: 7).

Territorial equity refers to the principle of liberty, that is the 'free exercise of the right to mobility of people and goods' to access the workplace, education, social activities, etc., which is a fundamental human right (PATS, 2000: 7). The freedom of movement may however be restricted by a road-user pricing system since road users may not be able to pay the toll tariff. The effect of territorial equity can be evaluated by the level of accessibility from the different zones to a relevant attraction area. Accessibility is determined by travel models. The access from zone a to opportunities in zone $b$ are weighed in terms of the travel costs between $a$ and $b$, and the average duration of travel. An improvement of accessibility is 
obtained when the value of time in terms of time saving is greater due to toll payment. Deterioration may occur if the value-of-time saving is less than the toll tariff and when alternative roads become more congested because of motorists avoiding the toll tariff. The cost and benefits of different zones in an area such as the GFIP project may, however, not be equitably distributed and should be evaluated separately.

Horizontal equity relates to equal opportunities and therefore to equal treatment of different road users, specifically in terms of the road-user pay principle. The user-pay principle can firstly relate to a tariff for externalities, such as pollution, noise and accidents as a result of road use, and secondly, to a tariff for improved infrastructure which enhances higher levels of service in terms of speed, reliability and comfort (Van Niekerk, 2009a). The userpay principle may however be in conflict with economic efficiency since the tariff covers all costs. The different categories of road users are those who continue to use a car, those who transfer from a car to public transport and those who continue to use public transport. The same travel conditions are applicable to all. Initially a category such as public transport may not be applicable to a project such as the GFIP since public transport is a very limited option. Another option may be to utilise alternative roads, if available. A change of consumer surplus for an individual category, such as the use of a car, can be determined by the average value of time, multiplied by the difference in time for that category, plus the difference in travel costs between the origin and destination.

Vertical equity relates to social inequalities, specifically disadvantaged groups who depend on transport as a necessity for their livelihood and well-being. Vertical equity 'consist of assessing the outcome of policies with reference to the well-being of the most disadvantaged, which one should attempt to maximise' (Raux \& Souche, 2004: 196). For SA, this equity requirement is of utmost importance since $51.5 \%$ of households in SA earn between RO and R50k (2008) and can therefore be regarded as financially disadvantaged (Masemola \& Van Wyk, 2009: xiv). The importance for the acceptance of a road-user pricing approach should be based on the fact that if the advantage of the improved road system is not financially substantially positive it may be regarded by road users as 'other tax' (Kocak et al., 2005: 392). Any non-discriminative toll tariff will be unacceptable in terms of the vertical equity principle because it may worsen the situation of those already financially disadvantaged and have no intention to improve their situation.

Based on the vertical equity approach, changes in the consumer surpluses of the different income groups should be determined to establish the impact of the toll. The consumer surplus of a specific income group is determined by the product of the average value of time and the time saving as a result of the improved infrastructure, plus the change in cost generated by the toll tariff. 
The above theoretical equity framework should be used to strategise an acceptable roaduser pricing approach and the management thereof. The new GFIP which is underway will be reviewed in terms of economic efficiency and equity issues.

\section{The Gauteng Freeway Improvement Project (GFIP)}

The National Department of Transport will invest R55 billion in Gauteng freeways. The first phase of the planned Gauteng Freeway requires more than R12 billion and should be completed in 2010. The completion of the second phase is planned for 2015, requiring an investment of R20 billion, and the third phase, requiring an investment of R23 billion, should be completed in 2018. 'This project will be financed through the "user-pay" principle and will allow our roads to be funded, without resorting to the national fiscus for such projects' (National Department of Transport, 2008). The GFIP will impact the geographical metropolitan areas of Tshwane (Pretoria) and Johannesburg positively but also negatively. Positive impacts will result from a modern road infrastructure for public transport, private and road freight users, but there will also be a negative impact on households if toll tariffs are not based on economic efficiency and socio-economic equity considerations. A roadtoll approach for a project such as GFIP may encounter more opposition than a rural road pricing approach because of the financial impact on a household's budget of members travelling daily on the toll road (Raux \& Souche, 2004: 192).

In 2008, the total number of Gauteng households was 3086 935. The income of 31.9\% of these households was between RO and R50k per year, and 25.4\% of households earned between R50k and R100k per year (Masemola \& Van Wyk, 2009: 22). Transport in Gauteng, as one of 22 household expenditure groups in the province, is the fourth highest expense (10.2\%) after food (20.1\%), housing and electricity (14.1\%) and income tax (10.7\%) (Masemola \& Van Wyk, 2009: 64). A non-discriminative toll tariff of 50 cents per kilometre, as proposed for the GFIP project (presumed to be $80 \%$ of the financial benefit of using the road), will have a substantial direct and indirect effect on the income groups R0-R50k and R50k-R100k because the lower the income of individuals the greater the value they attach to an additional unit of money. As such, Jara-Diaz and Videla (1989: 399) found in Santiago, Chile, the income effect of module choice was that the income elasticity rose six times towards the lowest level of income.

The objective of the GFIP is to provide an 'interconnected network of inner and outer ring roads, to directly link historically neglected areas of the Western and Southern townships of Johannesburg, and alleviate congestion experienced in Gauteng' (SANRAL, 2009a: 17). An electronic collection methodology with an open road tolling configuration (specialised gantries over the road and at the roadside) will be used for toll collections at 47 designated points, at freeway speed (SANRAL, 2009a: 49). A contract of R1.16 billion has been allocated to a private provider for implementing and operating the multilane free-flow tolling system (phase one), which is scheduled for April 2011 (SANRAL, 2009b). If such a road-user toll could be imposed on the fuel levy, the cost of recovery should be negligible. 
The GFIP project will specifically utilise a road-user pricing approach to ensure a sustainable road network. The user-pay principle will ensure dedicated funding for maintenance of the GFIP network, as well as expansion of the network in future to ensure congestion can be kept to a minimum (Van Niekerk, 2009a). Socio-economic benefits should be optimised, implying the maximum utilisation of road-user pricing research to arrive at 'a most acceptable tolling approach'. Scarce financial and land resources, especially available land surfaces in urban areas, are usually the motivation for urban road-user pricing, to generate compensation for the utilisation of such scarce resources (Raux \& Souche, 2004: 192).

The socio-economic acceptability of road-user pricing, especially in urban areas and projects such as GFIP, is important for societal coherence. When SANRAL's budget requests and the actual allocation by National Treasury are compared with the tax income raised from the fuel levy and vehicle licence taxes in Gauteng, it is evident that even Gauteng on its own generates more tax income from the road user than what is requested by SANRAL's total budget (see Table II). The total SANRAL allocation from National Treasury as a percentage of the actual Gauteng fuel levy and licence fee income for the 2007/08 financial year is approximately $24.23 \%$. It is therefore questionable why SANRAL does not attempt to apply for an allocation from National Treasury for financing the GFIP, or a part thereof, and so relieve the already burdened road user/tax payer. Without any reference of attempt to apply for an allocation from National Treasury, SANRAL concluded as follows on the GFIP: ' ... the feasibility study to implement the project as a user pay project has also been completed. It was concluded that the project can be funded on the user pay principle. A public participation process, the "intent to toll" process, was completed prior to award for the tenders.' However, the public participation process can unfortunately not be detected for scrutinising.

Table II: National Treasury allocation to SANRAL versus Gauteng fuel levy and provincial vehicle licence taxes

\begin{tabular}{|c|c|c|c|c|c|c|}
\hline $\begin{array}{c}\text { Description } \\
\text { (R'000) }\end{array}$ & $\begin{array}{c}\text { SANRAL's } \\
\text { budget } \\
\text { request }\end{array}$ & $\begin{array}{c}\text { National } \\
\text { Treasury } \\
\text { allocation } \\
\text { to SANRAL }\end{array}$ & $\begin{array}{c}{ }^{1} \text { Gauteng } \\
\text { fuel levy } \\
\text { tax }\end{array}$ & $\begin{array}{c}\text { 2Gauteng } \\
\text { vehicle } \\
\text { licence tax }\end{array}$ & $\begin{array}{c}\text { Gauteng } \\
\text { total: fuel } \\
\text { levy + vehicle } \\
\text { licence tax }\end{array}$ & $\begin{array}{c}\text { \% SANRAL } \\
\text { allocation from } \\
\text { fuel levy + } \\
\text { vehicle licences }\end{array}$ \\
\hline $2002 / 03$ & 1394686 & 1061060 & 5673506 & 2121400 & 6488336 & 16.35 \\
\hline $2003 / 04$ & 1854556 & 1170556 & 6161388 & 2538000 & 7136234 & 16.40 \\
\hline $2004 / 05$ & 2551536 & 1440780 & 7100448 & 2694900 & 8135559 & 17.71 \\
\hline $2005 / 06$ & 3715796 & 1756479 & 7587479 & 3299700 & 8854894 & 19.84 \\
\hline $2006 / 07$ & 5222250 & 1901060 & 8082502 & 3605800 & 9467490 & 20.08 \\
\hline $2007 / 08$ & 5451457 & 2476112 & 8783985 & 3639800 & 10182032 & 24.32 \\
\hline
\end{tabular}

Adapted from National Treasury, 2008:15-16; SANRAL, 2005:25.

${ }^{1}$ The Gauteng fuel levy is based on a $37 \%$ Gauteng average of contribution to the Gross Domestic Product (GDP).

${ }^{2}$ The Gauteng vehicle licence tax is based on a $38.41 \%$ Gauteng average of the national vehicle population (National Traffic Information System, 2010). 
SANRAL's original approach of a road-user pricing approach for the GFIP project relates to benefits that will be achieved in terms of general vehicle operating costs, value-of-time savings and external costs. However, SANRAL found 'a toll tariff structure substantially below the $80 \%$ of the user benefit' to be adequate to fund the project and therefore a cost-plus model, based on the actual cost of providing and operating the toll road, will be introduced. Market research done by SANRAL however showed 'that the issue of affordability of tolls by frequent users would have to be carefully considered in determining the actual toll tariffs and discount structures to be implemented because less than 400000 road users undertake more than $80 \%$ of the trips on the GFIP road network' (SANRAL, 2009a: 35).

The GFIP road-user pricing approach did not consider economic efficiency, territorial equity, horizontal equity or vertical equity. The direct link between historically neglected areas of the Western and Southern townships of Johannesburg specifically may have substantial direct and indirect financial implications on the income groups R0-R50k and R50k-R100k. Intentional discount rates for regular users do not distinguish between the different income groups and therefore fail to be regarded as a vertical equity consideration.

\section{CONCLUSION}

The structure of the national road infrastructure market in South Africa has the characteristics of a public monopoly because, inter alia, prices imperfectly reflect the interaction between supply and demand. Since the market is controlled by a public entity, namely SANRAL, it is generally expected that the wellbeing of citizens will be a top priority to ultimately 'improve the quality of life of all South African people'.

The national road infrastructure in South Africa should be economically viable, and be maintained to ensure the sustainability thereof. The necessary capital required for road investment and maintenance can be substantial, and is problematic because the taxes recovered by means of a general fuel levy and provincial licences are not allocated in full by National Treasury to SANRAL for road investment and maintenance. A road-pricing approach, specifically the development of toll roads, associated with a road-user pay principle, was developed by SANRAL to compensate for the deficit where necessary. However, the reasons for the under-allocation of funds by National Treasury is not questioned by SANRAL but rather used as motivation for tolling road users using the road. Economic efficiency, territorial equity, horizontal equity and vertical equity were not considered when SANRAL developed a road-user pricing approach. The latter may have serious consequences for financially disadvantaged citizens since the equality between the road users and providers of infrastructure (SANRAL) and therefore inequality between users and consumers may be at risk, specifically when the GFIP is operational. 
The total burden of financing national road infrastructure has more than fully become that of the road user, notwithstanding the fact that the contribution of roads to the country's economic welfare is indispensable and that all citizens, not only the road-user payers, share in this welfare.

Thorough research, such as the European research projects PATS and AFFORD, is vital to develop a national holistic approach to achieving the goals of a road-user charging strategy, while raising sufficient public support concurrently through economic efficiency, territorial equity, horizontal equity and vertical equity is necessary for national coherence. The concerns of the SA socio-economic public may be justifiable in their own right and should be alleviated through practical means, such as establishing a toll road regulator body to guard against unjustifiable toll tariffs and possible abuse of the South African road user. 


\section{REFERENCES}

AFFORD. 2001. Acceptability offiscal and financial measures and organisational requirements for demand management. Finland: Government Institute for Economic Research (VATT).

Archondo-Callao, R. 2004. Roads Economic Decision model - Software user guide and case studies. SSATP Working Paper No. 78. Sub-Saharan African Transport Policy Program (SSATP), World Bank.

Bonsor, N. C. 1984. Transportation economics. Toronto: Butterworths.

Copley, P. \& Shaw, A. 2007. Mechanisms and modalities for revenue collection and its allocation. Proceedings of the International Seminar on Road Financing and Investment, 19 April, Development Bank of Southern Africa, Tanzania

Haiden, R. M. \& Floor, B. 2003. Towards a policy on the imposition of road tolls in the City of Cape Town. Paper presented at the 22nd Annual South African Transport Conference, 14-16 July, Pretoria, South Africa.

Hensher, D. A. \& Brewer, A. M. 2001. Transport: An economics and management perspective. New York: Oxford.

Hensher, D. A. \& Puchett, S. M. 2005. Road user charging: The global relevance of recent developments in the United Kingdom. Transport Policy, 12(5): 377-83.

Infrastructure Consortium for Africa. 2007. Financing transport for growth in Africa: Wild Coast toll road - South Africa. Available from: http://www.icafrica.org/fileadmin/documents/ Transport_Meeting/S4-Wild-Coast-Toll-Road-Final-EN.pdf (accessed 20 July 2009).

Jansson, J. O. 2001. Editorial. Journal of Transport Economics and Policy, 35: 353- 62.

Jara-Diaz, S. R. \& Videla, J. 1989. Detection of income in mode choice: Theory and application. Transportation Research, 23B(6): 394-400.

Kocak, N. A., Jones, P. \& Whibley, D. 2005. Tools for road user charging scheme option generation. Transport Policy, 12: 391-405.

Masemola, M. E. \& Van Wyk, H. de J. 2009. Income and expenditure of households in South Africa, 2007-2008. Pretoria: Bureau of Market Research, Unisa.

National Department of Transport. 2006. Road infrastructure strategic framework for South Africa. Discussion document. Available from: http://www.transport.gov.za/library/docs/ rifsa/fund.html (accessed 13 July 2009). 
National Department of Transport. 2008. R55 billion for Gauteng freeways. Available from: http://www.sagoodnews.co.za/infrastructure/r55_billion_for_gauteng_freeways.html (accessed 1 September 2009).

National Traffic Information System (eNaTIS). 2010. Live vehicle population. Available from: http://www.enatis.com/Table/Live-Vehicle-Population-Statistics/ (accessed 5 January 2010).

National Treasury. 2008. Tax statistics. Pretoria: National Treasury and SARS.

Oberholzer, J. de V., Van Zyl, N. J. W., Andersen, S. J., Skrbinsek, D. \& Burnett, S. L. 2001. Traffic modelling of urban toll corridors: A review of current South African practice, as applied within the Johannesburg Pretoria toll corridor. Paper presented at the 20th Annual South African Transport Conference, 16-20 July, Pretoria, South Africa.

PATS. 2000. Socio-economic principles for price acceptability. PATS Project Deliverable D2, European Commission DG VII. Available from: http://www.tis.pt/proj/pats/Deliverable/ Deliverable2.pdf (accessed 1 July 2009).

Pienaar, W. J. \& Nel, J. H. 2009. Mathematical principles of road congestion pricing. ORiON, 25(1): 45-51.

Raux, C. \& Souche, S. 2004. The acceptability of urban road pricing: A theoretical analysis applied to experience in Lyon. Journal of Transport Economics and Policy, 38(2): 191-216.

Rawls, J. 1971. A theory of justice. Cambridge, MA: Harvard University Press.

Republic of South Africa. 1964. Customs and Excise Act, Act 91 of 1964 (as amended). Government Gazette No. 32830. Pretoria: Government Printers.

Republic of South Africa. 1998. The South African National Roads Agency Limited and National Roads Act of 1998. Government Gazette No.18798. Pretoria: Government Printers.

Rietveld, P. 2006. Pricing in transport: A multimodal perspective. An introduction. International Journal of Transport Economics, Engineering and Law, 32: 1-4.

Roth, G. 1996. Roads in a market economy. Aldershot, England: Ashgate.

Samuelson, P. A. \& Nordhaus, W. D. 1986. Economics. Singapore: McGraw-Hill.

SANRAL. 2005. Declaration of intent 2005-2008. Pretoria: Corporate Service.

SANRAL. 2009a. Declaration of intent 2009-2012. Pretoria: Corporate Service. 
SANRAL. 2009b. SANRAL awards contract for Gauteng toll system, 18 September. Available from: http://www.sanral.co.za/live/content.php?Item_ID=447 (accessed 13 January 2010).

SANRAL. 2009c. Socio-economic development: Statistics. Available from: http://www. sanral.co.za/live/content.php?Category_ID=35 (accessed 20 October 2009).

Taylor, I. 2000. The Maputo-Witbank toll road: Lessons for development corridors? Policy Brief No. 00/P5. Cape Town: Development Policy Research Unit, University of Cape Town.

Ubbels, B. 2005. The economics of transport pricing. NOW/Connekt VEV Project 014-34351: A multidisciplinary study of pricing policies in transport. Available from: http://www. onderzoekinformatie.nl/en/oi/nod/onderzoek/OND1297541/ (accessed 12 July 2009).

Van Niekerk, A. 2009a. Open-road toll system for Gauteng. Transport Forum. Sandton: Cedar Park Conference Centre.

Van Niekerk, A. 2009b. Personal interview, 17 August. Pretoria: SANRAL Office.

Verhoef, E. 1996. The economics of regulating road transport. Cheltenham: Edward Elgar.

Walter, F. \& Suter, S. 2003. Sustainable transport pricing: From theory towards application. Paper presented at the 16th ECMT Symposium, 29-31 October, Budapest, Hungary.

World Bank. 1999. Sustainable transport: Priorities for policy reform. Washington DC. World Bank Publication.

\section{Table of acronyms and abbreviations}

\begin{tabular}{|l|l|}
\hline AFFORD & $\begin{array}{l}\text { Acceptability of Fiscal and Financial Measures and Organisational Requirements for } \\
\text { Demand Management }\end{array}$ \\
\hline BOT & build operate transfer \\
\hline GFIP & Gauteng Freeway Improvement Project \\
\hline MPC & marginal private costs \\
\hline MSC & marginal social costs \\
\hline NDOT & National Department of Transport \\
\hline PATS & Pricing Acceptability in the Transport Sector \\
\hline PPP & public-private partnership \\
\hline SANRAL & South African National Roads Agency Ltd \\
\hline SATURN & Simulation and Assignment of Traffic to Urban Road Networks \\
\hline
\end{tabular}

